\title{
Complementary and Alternative Medicine Use for Musculoskeletal and Other Health Conditions -A Comparative Study Between two Ethnic Groups in Nigeria
}

\author{
Nwachukwu CC, Nwachukwu AC, Fatiregun AA, Owoaje ET
}

\begin{abstract}
Background Complementary and Alternative Medicine (CAM)are used for health promotion and disease treatment. Many options of CAM are exist.

Methods Comparative cross-sectional studyamong residents of Yoruba and Hausa ethnicity in Ibadan, Nigeria.WHO modified cluster sampling technique wasused to select 800 respondents, $\mathbf{4 0 0}$ from each study groups. Data were collected using semi-structured, interviewer administered questionnaire.

Results Lifetime CAM use was reported by $88.5 \%$ of Yoruba and $95.8 \%$ of Hausa respondents $(p<0.05)$ while $75.0 \%$ of Yoruba and $88.0 \%$ of Hausa were current CAM users ( $p$ 0.05). The most commonly used CAM were unprocessed herbal preparations by $64.0 \%$ of Yoruba and $79.5 \%$ of Hausa respondents $(p<0.05)$. Conditions for which respondents used unprocessed herbal preparation included febrile illnesses (Yoruba 45.1\%, Hausa 41.9\%), gastrointestinal conditions (Yoruba 4.9\%, Hausa 4.7\%), musculoskeletal conditions (Yoruba $\mathbf{2 . 8 \%}$, Hausa $\mathbf{2 . 2 \%}$ ) as well as for health promotion (Yoruba 4.9\%, Hausa 1.6\%); there was no statistical difference.

Predictors of lifetime CAM use were: being currently married [OR 2.22; 95\% CI 1.46 - 3.39], Islamic religion [OR 1.63; $95 \%$ CI 1.02 - 2.62] and Hausa ethnicity [OR 2.24; $95 \%$ CI 1.02 - 4.93]. Similarly, the predictors of current CAM use were being currently married [OR 2.77; 95\% CI 1.49-5.16], Islamic religion [OR 2.70; 95\% CI 1.35 - 5.41] and Hausa ethnicity [OR 1.38; 95\% CI 1.00 - 2.13].

Conclusion A high prevalence of CAM use was reported in both study groups. The conditions for which CAM was used were not significantly different.
\end{abstract}

Index Terms - alternative medicine, complementary medicine, Ibadan, Nigeria

\section{INTRODUCTION}

Complementary and alternative medicine (CAM) includes a wide range of health care systems, practices, and products that are not usually considered part of conventional medicine.[1]They are also known as unorthodox medicines. Unorthodox medicine is considered complementary medicine

Nwachukwu CC, Department of Community Medicine, Chukwuemeka OdumegwuOjukwu University, Awka, Anambra State.

Nwachukwu AC, Department of Surgery, Chukwuemeka OdumegwuOjukwu University, Awka, Anambra State.

Fatiregun AA, Department of Epidemiology, Medical Statistics and Environmental Health, Faculty of Public Health, University of Ibadan Nigeria.

Owoaje ET, Department of Community Medicine, University College Hospital, Ibadan, Nigeria. when it is used together with conventional medicine and as alternative medicine when it is used instead of conventional medicine. Modern medicine, however, is the officially approved dominant health system, often funded, patronized, and provided by the government for the people. Modern medicine go by other names such as allopathic, conventional, orthodox, scientific, classical, western, etc. Thesemedicines have been studied and have scientific evidence of safety and efficacy.[2]

For many centuries, people have used Complementary and Alternative Medicine (CAM)to promote health and treat diseases. The knowledge of these remedies have been handed down through generations.CAM is often referred to as unorthodox medicine. Many modern or orthodox medicine have their origin from unorthodox medicines. Health care professionals, however, tend to favour orthodox medicines over unorthodox medicine.

\section{METHODS}

A comparative, cross-sectional study carried out in Ibadan North Local Government Area, Oyo State. Two wards within the area were purposively selected for the study, Sabo (predominantly Hausa) and Inalende (predominantly Yoruba).[3] The World Health Organization (WHO) modified cluster sampling technique[4] was used to select study participants. Data was collected using semi-structured questionnaires. Chi square test was used to test associations between categorical variables at $5 \%$ level of significance. Multivariate analysis was done with binary logistics regression. Variables included in the enter method were those that were found to be significant from bivariate analysis at $\mathrm{p} \leq$ 0.2 , as well as factors that has been shown by other literature to be associated with CAM use. The enter method was used in running the logistic model. Predictors were those significant at $\mathrm{p}=0.05$.

The sample size was calculated using the formula for comparing two independent groups.[5]

$\mathrm{d}^{2}$

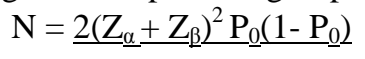

where $\mathrm{N}=$ minimum sample size

$\mathrm{P}_{0}=$ mean prevalence of CAM use in the 2 comparison groups i.e. $\left(\mathrm{P}_{1}+\mathrm{P}_{2}\right) / 2$

$\frac{\mathrm{P} 1+\mathrm{P} 2}{2}=\underline{0.69+0.47}=0.58$ 
$\mathrm{P}_{1}=0.69$. Previous estimate of CAM use among Yoruba population.[6]

$\mathrm{P}_{2}=0.47$. Previous estimate of CAM use among Hausa population.[6]

$\mathrm{d}=$ Difference between $\mathrm{P}_{1}$ and $\mathrm{P}_{2}=0.22$

$\mathrm{Z}_{\alpha}=$ Standard normal deviate corresponding to the probability $\alpha$, i.e. the probability of making a type 1 error at $5 \%=1.96$.

$\mathrm{Z}_{\beta}=$ the standard normal deviate at $80 \%$ statistical power, corresponding to the probability of making a type 2 error $=$ 0.84

$$
\begin{aligned}
& \mathrm{N}=\underline{2(1.98+0.84)^{2} 0.58(1-0.58)} \\
& 0.22^{2} \\
& \mathrm{~N}=387
\end{aligned}
$$

A total of 400 respondents were studied in each group.

\section{Definition of Terms}

- Unprocessed herbal preparations (unrefined herbal products) - herbal preparations and 'burantashi' (aphrodisiac).
- Processed herbal preparations (pharmaceutically processed herbal products) -Forever Living Products (FLP), GNLD, Tianshi, Tasly, YemKem, and Chinese medicine.

- Others - scarification, massage, python fat, bone setter, ritual sacrifices, incantations, wearing of charms, rings, urine therapy

- Current use of CAM refers to use in the last three months preceding the study.

- Urine therapy refers to the practice of drinking person's own urine.

- 'Pile' or 'jedijedi' (as used by the respondents) is a poorly defined symptom complex of back

pain, abdominal pain, constipation, problems with urination and defecation, passage of watery/mucoid stool,

\begin{tabular}{|c|c|c|c|c|c|}
\hline $\begin{array}{l}\text { Socio-demographic } \\
\text { characteristics }\end{array}$ & $\begin{array}{c}\text { Yoruba } \\
\mathrm{N}=400 \\
\mathrm{n}(\%)\end{array}$ & $\begin{array}{c}\text { Hausa } \\
\mathrm{N}=400 \\
\mathrm{n}(\%)\end{array}$ & $\begin{array}{c}\text { Total } \\
\mathbf{N}=800 \\
\text { n }(\%)\end{array}$ & $\begin{array}{c}\text { Statistics } \\
\chi^{2}\end{array}$ & p-value \\
\hline \multicolumn{6}{|l|}{ Age group (years) } \\
\hline$\leq 24$ & $40(10.0)$ & $119(29.8)$ & $159(19.9)$ & & \\
\hline $25-34$ & $150(37.4)$ & $137(34.2)$ & 287 (35.9) & & \\
\hline $35-44$ & $75(18.8)$ & $70(17.5)$ & $145(18.1)$ & & \\
\hline$\geq 45$ & $135(33.8)$ & $74(18.5)$ & $209(26.1)$ & 57.817 & $<0.001 *$ \\
\hline Mean age $( \pm S D)$ years & $40.1( \pm 15.8)$ & $32.6( \pm 12.8)$ & $36.4( \pm 14.9)$ & $7.360 * *$ & $<0.001 *$ \\
\hline \multicolumn{6}{|l|}{ Sex } \\
\hline Male & $165(41.2)$ & $209(52.2)$ & $374(46.8)$ & & \\
\hline Female & $235(58.8)$ & $191(47.8)$ & $426(53.2)$ & 9.721 & $0.002 *$ \\
\hline \multicolumn{6}{|l|}{ Marital status } \\
\hline Currently married & $306(76.5)$ & $243(60.8)$ & $549(68.6)$ & & \\
\hline Not currently married & $94(23.5)$ & $157(39.2)$ & $251(31.4)$ & 23.042 & $<0.001 *$ \\
\hline \multicolumn{6}{|l|}{ Religion } \\
\hline Christianity & $191(47.8)$ & $6(1.6)$ & $197(24.6)$ & & \\
\hline Islam & $209(52.2)$ & $394(98.4)$ & $603(75.4)$ & 2.413 & $<0.001 *$ \\
\hline \multicolumn{6}{|l|}{ Level of education } \\
\hline No formal & $59(14.8)$ & $95(23.8)$ & $154(19.2)$ & & \\
\hline Primary & $97(24.2)$ & $106(26.5)$ & $203(25.4)$ & & \\
\hline Secondary & $210(52.5)$ & $187(46.7)$ & 397 (49.6) & & \\
\hline Tertiary & $34(8.5)$ & $12(3.0)$ & $46(5.8)$ & 1.081 & $<0.001 *$ \\
\hline \multicolumn{6}{|l|}{ Occupation } \\
\hline Professional \& skilled & $142(35.5) 224$ & $86(21.5)$ & $228(28.4)$ & & \\
\hline Partly skilled & $(56.0)$ & $254(63.5)$ & $478(59.8)$ & & \\
\hline Unskilled & $34(8.5)$ & $60(15.0)$ & $94(11.8)$ & 22.829 & $<0.001 *$ \\
\hline \multicolumn{6}{|l|}{ Monthly income } \\
\hline$<\$ 10,000(\$ 28)$ & $245(61.2)$ & $269(67.2)$ & $514(64.2)$ & & \\
\hline$\geq \$ 10,000(\$ 28)$ & $155(38.8)$ & $131(32.8)$ & $286(35.8)$ & 3.135 & 0.077 \\
\hline
\end{tabular}
sexual dysfunction, etc.

Table 1: Socio-demographic characteristics

*Statistically significant $* *$ t-test

\section{A. Prevalence of CAM}

As shown in Table 2, the prevalence of CAM use among respondents was generally high. Including prayer, the prevalence of lifetime and current use of CAM was about $100 \%$ in both groups. Excluding prayer, use of CAM among the Hausa respondents was significantly higher than among Yoruba respondents both for having ever used CAM, 383 (95.8\%) compared to 354 $(88.5 \%)$, and for current use of CAM, $352(88.0 \%)$ compared to $300(75.0 \%)$ (p < 0.001$)$. 
Table 2: Prevalence of CAM use

\begin{tabular}{|c|c|c|c|c|c|}
\hline $\begin{array}{l}\text { Prevalence of use of } \\
\text { alternative medicine }\end{array}$ & $\begin{array}{l}\text { Yoruba } \\
\mathrm{N}=400 \\
\mathrm{n}(\%)\end{array}$ & $\begin{array}{l}\text { Hausa } \\
\mathrm{N}=400 \\
\mathrm{n}(\%)\end{array}$ & $\begin{array}{l}\text { Total } \\
\mathbf{N}=800 \\
\text { n }(\%)\end{array}$ & $\begin{array}{l}\text { Statistics } \\
\chi^{2}\end{array}$ & p-value \\
\hline $\begin{array}{l}\text { Lifetime CAM use (plus } \\
\text { prayer) }\end{array}$ & $400(100.0)$ & $399(99.8)$ & 799 (99.9) & 0.317 & 1.000 \\
\hline Ever used CAM & $354(88.5)$ & $383(95.8)$ & $737(92.1)$ & 0.000 & $<0.001 *$ \\
\hline Current CAM use & $300(75.0)$ & $352(88.0)$ & $652(81.5)$ & 0.000 & $<0.001 *$ \\
\hline
\end{tabular}

*Statistically significant

A significantly higher proportion of Hausa respondents 318 (79.5\%) used unprocessed local herbs compared to Yoruba respondents $256(64.0 \%)$, the figures for processed herbs were $80(20.0 \%)$ Hausa versus $40(10.0 \%)$ Yoruba and for other CAM products 185 (46.2\%) Hausa versus $132(33.0 \%)$ Yourba ( $<$ <0.001) as shown in Table 3.

Table 3: Current use of CAM

\begin{tabular}{|c|c|c|c|c|c|}
\hline CAM groups & $\begin{array}{c}\text { Yoruba } \\
\mathrm{N}=400 \\
\mathrm{n}(\%)\end{array}$ & $\begin{array}{c}\text { Hausa } \\
\mathrm{N}=400 \\
\mathrm{n}(\%)\end{array}$ & $\begin{array}{c}\text { Total } \\
\mathbf{N}=\mathbf{8 0 0} \\
\mathbf{n}(\%)\end{array}$ & $\begin{array}{c}\text { Statistics } \\
\chi^{2}\end{array}$ & p-value \\
\hline $\begin{array}{l}\text { Unprocessed herb } \\
\text { preparations } \\
\text { Yes }\end{array}$ & & & & & \\
\hline No & $\begin{array}{l}256(64.0) \\
144(36.0)\end{array}$ & $\begin{array}{l}318(79.5) \\
82(20.5)\end{array}$ & $\begin{array}{l}574(71.8) \\
226(28.2)\end{array}$ & 23.706 & $<0.001 *$ \\
\hline $\begin{array}{l}\text { Processed herbal } \\
\text { preparations }\end{array}$ & & & & & \\
\hline $\begin{array}{l}\text { Yes } \\
\text { No }\end{array}$ & $\begin{array}{l}40(10.0) \\
360(90.0)\end{array}$ & $\begin{array}{l}80(20.0) \\
320(80.0)\end{array}$ & $\begin{array}{l}120(15.0) \\
680(85.0)\end{array}$ & 15.686 & $<0.001 *$ \\
\hline $\begin{array}{l}\text { Other CAM } \\
\text { Yes } \\
\text { No }\end{array}$ & $\begin{array}{l}132(33.0) \\
268(67.0)\end{array}$ & $\begin{array}{l}185(46.2) \\
215(53.8)\end{array}$ & $317(39.6)$ & 14.677 & $<0.001 *$ \\
\hline
\end{tabular}

Figure 1shows that prayer/faith healing, herbs, massage and scarification were the most ever used alternative medicines by the respondents. A higher proportion of Yoruba respondents had used prayer/faith healing, massage and scarification in their lifetime while a higher proportion of Hausa respondents had ever used herbal preparations.

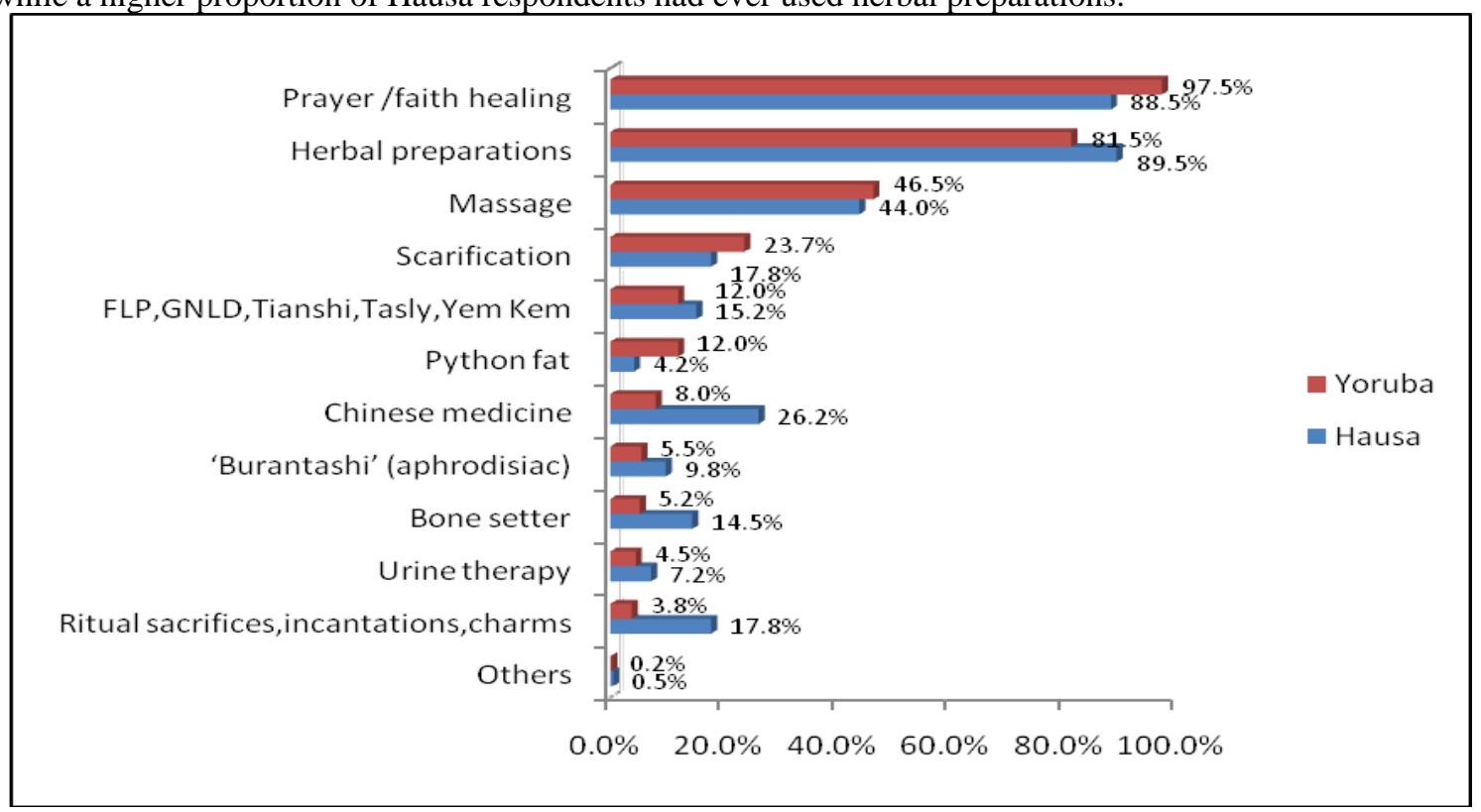

Figure 1: Lifetime use of CAM (including prayer) 

Study Between two Ethnic Groups in Nigeria

Figure 2 shows that the pattern of current use of alternative medicine was different from lifetime use. Prayer/faith healing, herbal preparations, massage, ritual sacrifices, incantations and charms were the most currently used CAM. A higher proportion $(96.2 \%)$ of Yoruba respondents currently use prayer/faith healing compared to $88.5 \%$ of Hausa respondents. Whereas a higher proportion of Hausa respondents currently use herbal preparations, massage, ritual sacrifices, incantations and charms compared to Yoruba respondents.

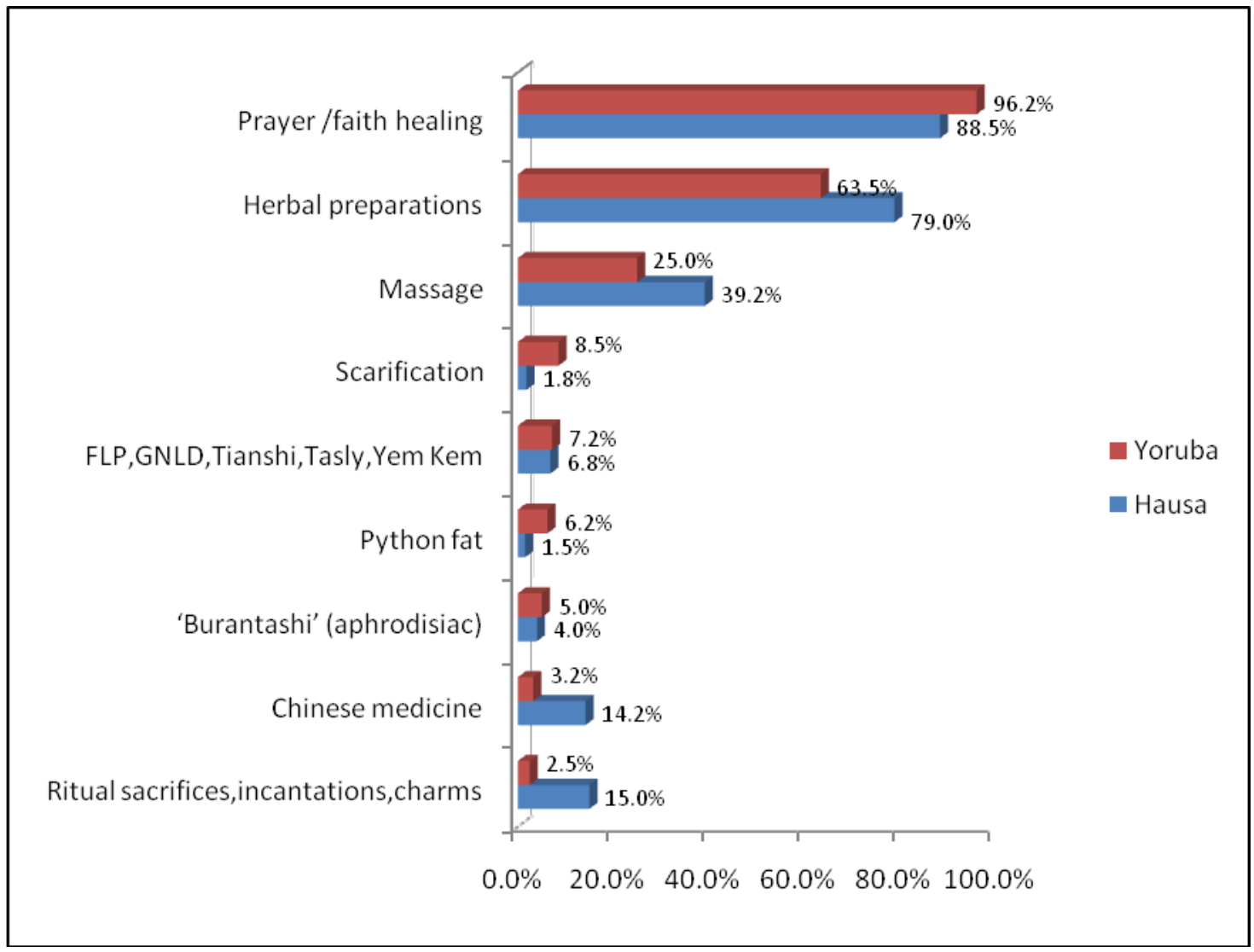

Figure 2: Current use of CAM (including prayer)

A majority of both Yoruba respondents (95.7\%) and Hausa respondents (81.0\%) used alternative medicines the last time they were ill rather than orthodox/modern medicine as shown in Figure 3. No respondent used a combination of both alternative and orthodox medicine.

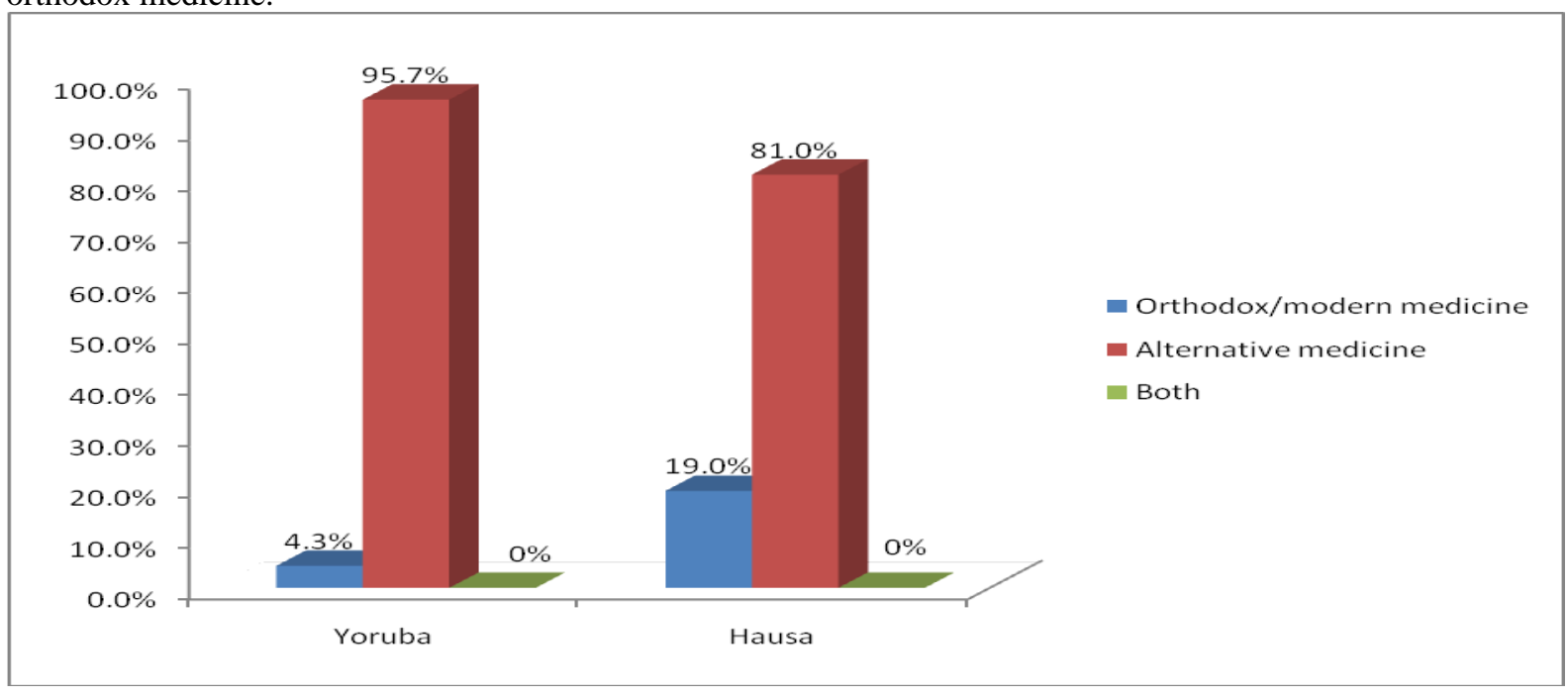

Figure 3: Treatment type used by respondents during the last episode of illness 


\section{B. Health problems for which CAM was used}

Health problems prompting respondents' most recent use of herbal products (unprocessed or processed) are displayed in Table 4. There was no statistical difference between the health problems for which CAM was used among Yoruba and Hausa respondents. Majority of Yoruba respondents used local herbal concoctions for febrile conditions, 147 (45.1\%) and 'jedijedi' $117(35.9 \%)$ while a higher proportion of Hausa respondents used CAM for headache, toothache, fibroid, hypertension, diabetes, asthma, arthritis, skin problems, stress and stroke $(\mathrm{p}=0.240)$.

Similar proportions of Yoruba and Hausa respondents used other CAM like massage, scarification, python fat and urine therapy as shown in Table 5.

Table 4: Health problems for the most recent use of unprocessed and processed herbal preparations

\begin{tabular}{|c|c|c|c|c|c|}
\hline Health problems & $\begin{array}{l}\text { Yoruba } \\
\text { n }(\%)\end{array}$ & $\begin{array}{l}\text { Hausa } \\
\text { n }(\%)\end{array}$ & $\begin{array}{l}\text { Total } \\
\text { n }(\%)\end{array}$ & $\begin{array}{l}\text { Statistics } \\
\chi^{2}\end{array}$ & p-value \\
\hline Herbal preparation & $(n=326)$ & $(n=358)$ & $(n=684)$ & & \\
\hline Febrile conditions & $147(45.1)$ & $150(41.9)$ & $297(45.3)$ & & \\
\hline 'Pile' or 'jedijedi' & $117(35.9)$ & $99(27.7)$ & $216(33.0)$ & & \\
\hline Gastrointestinal conditions & $16(4.9)$ & $16(4.7)$ & $32(4.9)$ & & \\
\hline Health promotion & $16(4.9)$ & $7(1.6)$ & $23(3.4)$ & & \\
\hline Musculoskeletal conditions & $9(2.8)$ & $8(2.2)$ & $17(1.2)$ & & \\
\hline Others & $21(6.4)$ & $78(21.8)$ & $99(15.8)$ & 24.057 & 0.240 \\
\hline Chinese medicine & $(n=32)$ & $(n=105)$ & $(n=137)$ & & \\
\hline Musculoskeletal & $10(31.3)$ & $28(26.6)$ & $38(27.7)$ & & \\
\hline Febrile conditions & $7(21.9)$ & $14(13.4)$ & $21(15.3)$ & & \\
\hline Gastrointestinal conditions & $8(25.0)$ & $20(19.1)$ & $28(20.5)$ & & \\
\hline 'Pile' or 'jedijedi' & $5(15.6)$ & $4(3.8)$ & $9(6.6)$ & & \\
\hline Others & $2(6.3)$ & $39(37.1)$ & $41(29.9)$ & 20.728 & 0.239 \\
\hline $\begin{array}{l}\text { FLP, GNLD, Tianshi, Tasly, } \\
\text { YemKem }\end{array}$ & $(n=48)$ & $(n=61)$ & $(n=109)$ & & \\
\hline Non-communicable diseases & $10(20.8)$ & $17(27.9)$ & $27(24.8)$ & & \\
\hline Febrile conditions & $9(18.8)$ & $10(16.4)$ & $19(17.4)$ & & \\
\hline Health promotion & $5(10.3)$ & $9(14.8)$ & $14(12.8)$ & & \\
\hline 'Pile' & $3(6.3)$ & $10(16.4)$ & $13(11.9)$ & & \\
\hline Respiratory conditions & $8(16.7)$ & $3(4.9)$ & $11(10.1)$ & & \\
\hline Gastrointestinal conditions & $7(14.6)$ & $4(6.5)$ & $11(10.1)$ & & \\
\hline Others & $6(12.5)$ & $8(13.1)$ & $14(12.9)$ & 21.828 & 0.240 \\
\hline 'Burantashi' (aphrodisiac) & $(\mathrm{n}=22)$ & $(n=39)$ & $(n=61)$ & & \\
\hline Impotence/ low libido & $15(68.2)$ & $9(23.1)$ & $24(39.3)$ & & \\
\hline Infertility & $5(22.7)$ & $13(33.3)$ & $18(29.5)$ & & \\
\hline Others & $2(9.1)$ & $17(43.6)$ & $19(31.2)$ & 5.129 & $0.024 *$ \\
\hline
\end{tabular}

*Statistically significant 
Complementary and Alternative Medicine Use for Musculoskeletal and Other Health Conditions -A Comparative Study Between two Ethnic Groups in Nigeria

Table 5: Health problems for the most recent use of other CAM

\begin{tabular}{|c|c|c|c|c|c|}
\hline Health problems & $\begin{array}{c}\text { Yoruba } \\
\text { n }(\%)\end{array}$ & $\begin{array}{c}\text { Hausa } \\
\text { n }(\%)\end{array}$ & $\begin{array}{l}\text { Total } \\
\text { n }(\%) \\
\end{array}$ & $\begin{array}{c}\text { Statistics } \\
\chi^{2}\end{array}$ & p-value \\
\hline Massage & $(n=186)$ & $(n=176)$ & $(n=362)$ & & \\
\hline Musculoskeletal conditions & $139(74.7)$ & $108(64.4)$ & $247(68.2)$ & & \\
\hline Febrile conditions & $23(12.4)$ & $23(13.1)$ & $46(12.7)$ & & \\
\hline Stress & $16(8.6)$ & $19(10.8)$ & $35(9.7)$ & & \\
\hline Others & $8(4.3)$ & $26(14.8)$ & $34(9.4)$ & 13.856 & 0.536 \\
\hline Scarification & $(\mathbf{n}=95)$ & $(n=71)$ & $(n=166)$ & & \\
\hline Musculoskeletal conditions & $34(35.8)$ & $29(40.8)$ & $63(38.0)$ & & \\
\hline Protection & $24(25.3)$ & $16(22.5)$ & $40(24.1)$ & & \\
\hline Health promotion & $20(21.0)$ & $7(9.9)$ & $27(16.3)$ & & \\
\hline Febrile conditions & $10(10.5)$ & $9(12.7)$ & $19(11.4)$ & & \\
\hline Others & $7(7.4)$ & $10(14.1)$ & $17(10.2)$ & 16.302 & 0.362 \\
\hline Ritual sacrifice, charms, etc & $(n=15)$ & $(n=71)$ & $(n=86)$ & & \\
\hline Protection & $9(60.0)$ & $38(53.5)$ & $47(54.7)$ & & \\
\hline Health promotion & $2(13.3)$ & $10(14.1)$ & $12(13.9)$ & & \\
\hline Musculoskeletal conditions & $2(13.3)$ & $3(4.2)$ & $5(5.8)$ & & \\
\hline Others & $2(13.3)$ & $20(28.2)$ & $22(25.6)$ & 1.013 & 0.962 \\
\hline Bone setters & $(\mathrm{n}=21)$ & $(n=58)$ & $(n=79)$ & & \\
\hline Fracture & $12(57.1)$ & $48(82.6)$ & $60(75.9)$ & & \\
\hline Sprain & $8(38.1)$ & $7(12.1)$ & $15(19.0)$ & & \\
\hline Body pain & $1(4.8)$ & $3(5.3)$ & $4(5.1)$ & 9.394 & 0.495 \\
\hline Python fat & $(n=48)$ & $(\mathrm{n}=17)$ & $(n=65)$ & & \\
\hline Musculoskeletal conditions & $19(39.6)$ & $6(35.3)$ & $25(38.5)$ & & \\
\hline Dermatological conditions & $17(35.4)$ & $8(47.1 .0)$ & $25(38.5)$ & & \\
\hline Febrile conditions & $4(8.3)$ & $2(11.8)$ & $6(9.2)$ & & \\
\hline Others & $8(16.7)$ & $1(5.9)$ & $9(13.8)$ & 4.531 & 0.717 \\
\hline Urine therapy & $(n=18)$ & $(n=29)$ & $(n=47)$ & & \\
\hline Dermatological conditions & $6(33.3)$ & $12(41.4)$ & $18(38.3)$ & & \\
\hline Health promotion & $4(22.2)$ & $2(6.9)$ & $6(12.8)$ & & \\
\hline Febrile conditions & $3(16.7)$ & $4(13.8)$ & $7(14.9)$ & & \\
\hline Others & $5(27.8)$ & $11(37.9)$ & $16(34.0)$ & 14.667 & 0.066 \\
\hline
\end{tabular}

\section{DISCUSSION}

CAM was used by the majority of the population with over three-quarters of both study populations currently using at least one form of CAM. The prevalence of use for both groups was much higher than that reported in a community based survey of Indians living in South Africa where about 4 out of 10 persons used CAM.[7]An American study[8] showed that less than a fifth of respondents use herbs compared to about three-quarters of the respondents in this study. Also a multisite, multiethnic, study in America reported that more than half of women used some type of CAM[9] whereas as more than four-fifth of women in this study use CAM.

Prayer was a major contributor to the relatively high use rate among cancer patients in Brazil. Excluding prayer, use of indigenous traditional medicine was found to be relatively low.[10] On the contrary, the prevalence of CAM use in this study was high regardless of prayer. An overall lifetime and current CAM use of $92.1 \%$ and $81.5 \%$ in this study is higher than $85 \%$ and $52 \%$ found in a community based, rural and urban multisite study in Australia.[11]

The use of CAM was also much lower (38\%) in America[1] and the types of CAM used differed remarkably from what was found in our study. While meditation, acupuncture and yoga were commonly reported in the American study they were non-existent in this study. The types of CAM identified by this studies including performing rituals and bloodletting/scarification are similar to those of other studies in Zaire(sub-Saharan Africa),[12] Aba,[13] and Benin City[14].

The most frequently used CAM by respondents in this study was found to be herbal medicines. Herbal treatments was also reported by the WHO as the most popular form of traditional medicine, and are increasingly lucrative in the international marketplace.[15] Although a higher proportion of Hausa respondents in this study reported using local herbal preparation, the proportion of Yorubas who used them for the treatment of febrile conditions $(45.1 \%)$ was slightly higher than Hausas $(41.9 \%)$. Thefindings was similar to that in Lagos state where a higher proportion of Yorubas $(69 \%)$ than Hausas (47\%) use herbs in treating malaria.[6]

The pattern of use of CAM was also different. While the American respondents used CAM as an adjunct to, rather than a substitute for orthodox medical care, our study found that although more than four-fifths used alternative medicine during their last illness, none combined both alternative and orthodox medicine. A similar result was shown by another study where the majority of those who used unconventional therapy for serious medical conditions in America, also sought treatment for the same condition from a medical doctor.[16] Similarly, a national survey in America reported that only very few $(4.4 \%)$ of those surveyed said that they relied primarily on alternative therapies.[17] A few 
respondents (1.9\%) obtained information on CAM from hospital staff as similarly reported by $3 \%$ of American respondents.[18]

The commonest health conditions for which respondents in this study used CAM were febrile conditions, 'pile'/'jedijedi', gastrointestinal conditions and health promotion. This is similar to finding in Nepal where abdominal pain, fever and diarrhoea were the commonest illness for which respondents used CAM.[19] On the contrary, American adults were most likely to use CAM for musculoskeletal problems such as back pain, neck pain, joint pain as well as for colds and anxiety/stress.[1] Another study in America found hypertension, headache and promoting health to be the commonest conditions for the use of CAM.[20] This is expected because the burden of communicable diseases in developing countries is still high unlike in developed countries.

\section{REFERENCES}

[1] National Centre for Complementary and Alternative Medicine. The use of Complementary and Alternative Medicine in the United States 2007.

[2] Umaru FA. Modern and traditional medicine, conflicts and reconciliation. 1st ed. Ibadan: Spectrum books limited; 2006.

[3] National Bureau of Statistics. Federal Republic of Nigeria 2006 population census.

[4] World Health Organization. The EPI coverage survey1991.

[5] Kelsey JL, editor. Methods in observational epidemiology. USA: Oxford University Press; 1996.

[6] Idowu E, Mafe MA, Otubanjo OA, Adeneye AK. Herbal remedy in the treatment of malaria: cross sectional survey of residents of Lagos State, Nigeria. Afr J Med Med Sci. 2006 June;35(2):149-53.

[7] Singh V, Raidoo DM, Harris CS. The prevalence, pattern of usage and people's attitude towards complementary and alternative medicine (CAM) among the Indian community in Chatsworth, South Africa. BMC Complement Alternative Medicine. 2004;4:3.

[8] Kaufman D, Kelly, JP, Rosenberg, L, Anderson, TE, Mitchell, AA. Recent patterns of medication use in the ambulatory adult population of the United States: The Slone Survey. JAMA. 2002;287(3):337-44.

[9] Gold E, Bair Y, Zhang G, Utts J, Greendale GA, Upchurch D, Chyu L, Sternfeld B, Adler S. Cross-sectional analysis of specific complementary and alternative medicine (CAM) use by racial/ethnic group and menopausal status: the Study of Women's Health Across the Nation (SWAN). Menopause 2007;14(4):612-23.

[10] Philip T. Use of traditional medicine and globalized complementary and alternative medicine among low-income cancer service users in Brazil. Integrative Cancer Therapies. 2006;5(3):232-5.

[11] Robinson A, Cooper S. Trusted Information Sources: The Preferred Option for Complementary and Alternative Medicine Users. Complementary Health Practice Review. 2007;12(2):120-38.

[12] Hrdy DB. Cultural Practices Contributing to the Transmission of Human Immunodeficiency Virus in Africa. Reviews of infectious diseases. 1987;9(6):1109-19.

[13] Chapp-Jumbo A. Traditional practices affecting child health: a sub-saharan African experience. Pediatrics 2008;121:S97.

[14] Akenzua GI, Akpovi SU, Ogbeede O. Maternal and Child Care in Rural Areas: the Role of Traditional Birth Attendants in Bendel State of Nigeria. Journal of Tropical Pediatrics. 1981;27:210-4.

[15] World Health Organization. Traditional Medicine 2008 Contract No.: Fact sheet No. 134

[16] Eisenberg DM, Kessler RC, Foster C, Frances E. Norlock FE, Calkins DR, Delbanco TL. Unconventional Medicine in the United States -Prevalence, Costs, and Patterns of Use. N Engl J Med. 1993;328:246-52.

[17] Astin JA. Why Patients Use Alternative Medicine, Results of a National Study. JAMA. 1998;279(19):1548-53.

[18] Archer EL, Boyle DK. Herb and Supplement Use Among the Retail Population of an Independent, Urban Herb Store. J Holist Nurs. 2008;26(1):27-35.

[19] Praveen P, Ravi, S, Nagesh, S A study on the use of complementary and alternative medicine therapies in and around Pokhara sub-metropolitan city, western Nepal 2002.
[20] Munstedt K, Harren H, Georgi RV, Hackethal A. Complementary and alternative medicine: comparison of current knowledge, attitude and interest among German medical students and doctors. eCAM [serial on the Internet]. 2008. 